\title{
ICT Small Businesses' Access To Bank Financing
}

Ramzi Benkraiem, IESEG School Of Management (LEM-CNRS, UMR 8179), France Anthony Miloudi, La Rochelle Business School, CRIEF, France

\begin{abstract}
Studying small businesses in the ICT industry is of major importance for at least two reasons. First of all, small businesses play a crucial role in supporting growth and creating jobs. Secondly, the ICT industry in France, as in most developed countries, is one of the pillars upon which tomorrow's economy will be built. Therefore, this article aims at studying access to bank financing by French small businesses in the ICT industry. The analysis covers a sample of 539 firm-years. The empirical results seem to show that these businesses encounter difficulties accessing bank debt and financing their assets, among other things. These difficulties are particularly more significant for small businesses in the 'service' segment than for those in the 'production' segment.
\end{abstract}

Keywords: Bank Debt; Financing; Small Businesses; ICT Industry

\section{INTRODUCTION}

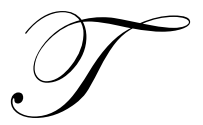

he term "small business" covers various realities. Although these firms all fulfill the size and staffing criteria (European Commission, 2005), it is possible to differentiate several categories according to their financing needs. This is particularly the case of small businesses in the Information and Communication Technology (ICT) industry. These firms develop fundamental communications, information systems, connection, measuring and monitoring devices, computer equipment, products and services, etc. ICTs constitute a labor and efficiency factor for all firms. Studies conducted by the French Ministry for the Economy, Finance, and Industry and IDATE ${ }^{1}$ have shown that ICTs' productive activities represent about $5 \%$ of France's GDP. Moreover, nearly $20 \%$ of firms' equipment investments involve products and services provided by ICTs.

ICT industry small business development and durability depend mainly on how they finance their growth. Yet, the presence of intangible assets in their balance sheets, in particular those in the service segment, gives pause to credit institutions. Indeed, classic low-risk debt, guaranteed by physical collateral, seems inappropriate for their characteristics. Therefore, examining these small businesses' access to bank financing is a major issue.

A large number of previous studies have looked at small businesses' access to bank debt in various contexts. We can identify two major currents. The first falls under a macroeconomic approach, linking access to bank credit to monetary policies implemented by central banks (Oliner and Rudebusch, 1996; Kashyap et al., 1996; Atanasova and Wilson, 2004). The second develops a microeconomic analysis of access to credit based on the firm's specific determinants (Bougheas et al., 2006; Gonzales et al., 2007; Kremp and Stoss, 2001; Ziane, 2004). These authors are primarily based on the precepts of the pecking order theory and the static trade-off theory. This article falls under the second current. It studies the link between several corporate characteristics of small businesses and bank debt, focusing specifically on the ICT industry. Like Cassar and Holmes (2003) and Sogorb-Mira (2005), we have used these two theories as a basis for deducing a set of determinants for access to bank debt for our sample of 539 firm-years during a period of 4 years from 2003 to 2006.

\footnotetext{
${ }^{1}$ Interested readers may consult the French Ministry of the Economy, Finance, and Industry's document titled: Information Technologies and Communications: Industries, Services, and Wholesale Trade [in French], as well as an IDATE article: ICT Industry Competition [in French], downloadable from their site: www.idate.org.
} 
The empirical results seem to show that these businesses encounter difficulties accessing bank debt and financing their assets, among other things. These difficulties seem particularly more significant for small businesses in the 'service' segment than for those in the 'production' segment. These results may interest researchers and finance professionals while contributing to a better understanding of access to bank financing by small business in the ICT industry. They may also be used by governmental authorities during a period when small business financing is primordial (Aubier and Cherbonnier, 2007).

The rest of the paper is organized as follows: Section 2 presents the theoretical background for deducing determinants of access to bank financing by small business in the ICT industry. Section 3 presents the data as well as the methodology deployed in this study. Section 4 conveys the empirical results obtained. Lastly, Section 5 presents the conclusion.

\section{THEORETICAL FRAMEWORK}

As outlined above, the static-trade off and pecking-order theories are used to deduce determinants of accessing bank debt by small businesses in the ICT industry. This issue is strategic. Indeed, taking into account the importance of developing ICTs for the economy, it seems fundamental to focus on the extent and range of these theories for this group of firms.

The trade-off theory provides an explanation of how firms maximize their shareholder value by determining an optimal debt ratio. This theory is based on arbitrating the costs of bankruptcy, agency costs, savings garnered by using debt, in the form of tax write-offs for interest. It takes three factors into consideration: tax savings, the cost of financial distress, and agency costs (Jensen and Meckling, 1976). Financial distress costs include direct and indirect costs related to the liquidation and reorganization process when firms are subject to recovery proceedings. Such costs may be significantly higher for small businesses (Andrade and Kaplan, 1998). They vary based on industry, size, and tangibility of assets. These costs occur when the firm is confronted with conflicts of interest between its various stakeholders, particularly between directors and capital contributors. When the company takes on debt, a conflict of interest may occur since investment decisions have different consequences on the value of own capital and the debt. In this context, directors may make decisions in favor of shareholders but detrimental to creditors.

The static-trade off theory developed by Myers (1984) and Myers and Majluf (1984) proposes that firms have a preferential order for financing. In particular, this theory highlights the fact that managers have more information than the capital contributors with regards to the financial decisions affecting the firm. This informational asymmetry between managers, creditors, and shareholders is at the heart of this approach. Firms favor self-financing above all, then short-term debt, followed by long-term debt, and lastly issuing stock. Therefore, this theory explains why the least profitable firms are generally those with the most debt since they do not have sufficient internal financial resources.

This theoretical development may be adapted to small businesses in the ICT industry. These firms reflect a certain number of specificities. In particular, their economic model is based on innovation and developing human capital. These elements induce greater risk-taking for funds contributors particularly due to the uncertain return on investment. This attitude of creditors with regards to ICT industry small business risk may be explained firstly by the likelihood of bankruptcy. Indeed the direct and indirect costs of bankruptcy may be particularly important. These firms' assets are primarily immaterial, difficultly transferrable if the company is liquidated. In this context, managers, wishing to maximize shareholder value, will be incited to make more risky investments since they are potentially more profitable. Therefore, the agency costs increase between managers-shareholders and creditors. The presence of financial distress and agency costs may explain why certain ICT firms have a relatively low debt level.

This low debt level for small businesses in the ICT industry may also be explained by the existence of a credit rationing phenomenon. This phenomenon also arises from the informational asymmetry between lenders (creditors) and borrowers (managers). Stiglitz and Weiss (1981) precise that this rationing results from the difficulty banks have evaluating the risk of investment projects due to a lack of reliable information about firms. Their only adjustment variable remains setting the interest rate. In reality, banks offer an average interest rate and ration the 
most risky borrowers. So the availability of debt is directly related to the risk. This notion of risk may affect the prediction of both the static trade-off and pecking order theories by increasing bankruptcy and agency costs.

In-line with some previous studies (Drobandz and Fix, 2005; Cassar and Holmes, 2003, etc.), these two static trade-off and pecking order theories are implemented to deduce the characteristics of small businesses deemed to be determinant of bank financing. So, several variables are considered, i.e. total assets (TA), profitability (PR), sales growth (GR), asset tangibility (AT), earnings volatility (VO) and investment opportunities (IO).

Total assets may mean greater stability and less risk for banks. A positive relationship is expected between total assets and bank financing (Chittenden et al., 1996 and Michaelas and al., 1999).

Profitability may facilitate access to bank debt for small businesses. However, these firms may prefer to finance their investment projects using their internal resources since bank debt, like external resources, is costly in terms of control and independence. This reasoning supports a negative relationship between ICT industry small businesses' profitability and bank debt (Chittenden et al., 1996; Jordan et al., 1998; Michaelas et al., 1999).

Asset tangibility may increase the firm's liquidation value thereby reducing the risk for funds contributors. Tangibility should therefore be positively related to the firm's bank debt (Jordan et al., 1998; Michaelas et al., 1999; Cassar and Holmes, 2003).

Earnings volatility may also increase the risk of insolvency in the eyes of banks. It may also increase information asymmetry issues between managers and lenders since the later will have problems with high volatility in anticipating future results (DeAngelo and Masulis, 1980). Volatility must therefore have a negative relationship with the bank debt.

Lastly, several previous studies have used Tobin's Q ratio to identify investment opportunities (Gugler et al., 2004; Blose and Sheih, 1997). This ratio, defined as the ratio between the firm's market value and accounting value, is used as a measurement of investment opportunities. An average of this ratio greater than 1 means that the firm presents profitable investment opportunities and vice versa (Lang and Litzenberger, 1989). A high level in this ratio may reveal significant financing needs. Consequently, this ratio should be positively correlated to bank debt.

\section{METHOD AND DATA COLLECTION}

\section{Data Collection}

The financial information used in this study comes from Diane. This database includes, among other things, financial reports of French companies listed on the Paris stock exchange. The starting sample is composed of all non-financial small businesses, or assimilated, available during the 4 year period from 2003 to 2006. Companies with missing data have been excluded. Then, we extracted firms from the ICT industry. Moreover, we have excluded all those small businesses undergoing recovery proceedings in order to prevent the presence of aberrant data during statistical processing. In the end, the sample is composed of 539 firm-years employing less than 250 people, with sales under $€ 50$ million, and whose balance sheet does not exceed $€ 43$ million (European Commission criteria, $2005^{2}$ ).

\section{Method}

The empirical analysis is based on two multiple regression models presented below that we estimate for the entire study period (pooled regression) using the ordinary least squares (OLS) approach. We use the OLS approach in order to facilitate comparing this article's results with previous studies (Cassar and Holmes, 2003, Sogorb-Mira, 2005, etc.).

\footnotetext{
${ }^{2}$ European Commission (2005), The New SME Definition: User Guide and Model Declaration, (downloadable at the following address: http://ec.europa.eu/enterprise/enterprise_policy/sme_definition/sme_user_guide.pdf).
} 
Model [1]:

$\mathrm{BD}_{\mathrm{it}}=\alpha_{0}+\alpha_{1} \mathrm{TA}_{\mathrm{it}}+\alpha_{2} \mathrm{PR}_{\mathrm{it}}+\alpha_{3} \mathrm{GR}_{\mathrm{it}}+\alpha_{4} \mathrm{TA}_{\mathrm{it}}+\alpha_{5} \mathrm{VO}_{\mathrm{it}}+\alpha_{6} \mathrm{IO}_{\mathrm{it}}+\sum_{\mathrm{k}=2004}^{2006} \alpha_{\mathrm{K}} \mathrm{Year} \mathrm{K}+\varepsilon_{\mathrm{it}}$

Model [2]:

$\mathrm{BD}_{\mathrm{it}}=\beta_{0}+\beta_{1} \mathrm{SI}+\beta_{2}(\mathrm{PI} \times \mathrm{TA})_{\mathrm{it}}+\beta_{3}(\mathrm{SI} \times \mathrm{TA})_{\mathrm{it}}+\beta_{4}(\mathrm{PI} \times \mathrm{PR})_{\mathrm{it}}+\beta_{5}(\mathrm{SI} \times \mathrm{PR})_{\mathrm{it}}+\beta_{6}(\mathrm{PI} \times \mathrm{GR})_{\mathrm{it}}$

$+\beta_{7}(\mathrm{SI} \times \mathrm{GR})_{\mathrm{it}}+\beta_{8}(\mathrm{PI} \times \mathrm{TA})_{\mathrm{it}}+\beta_{9}(\mathrm{SI} \times \mathrm{TA})_{\mathrm{it}}+\beta_{10}(\mathrm{PI} \times \mathrm{VO})_{\mathrm{it}}+\beta_{11}(\mathrm{SI} \times \mathrm{VO})_{\mathrm{it}}+\beta_{12}(\mathrm{SI} \times \mathrm{IO})_{\mathrm{it}}$

$+\beta_{13}(\mathrm{PI} x \mathrm{OI})_{\mathrm{it}}+\sum_{\mathrm{k}=2004}^{2006} \alpha_{\mathrm{K}}$ Year K $+\varepsilon_{\mathrm{it}}$

The dependant variable is, for each small business $i$, year $t$, defined as follows:

- $\quad \mathrm{BD}=$ Financial bank debt divided by total assets;

This variable is analyzed as a bank financing ratio, where the numerator is formed of all bank debts and the denominator by total assets. Bougheas et al. (2006) specify that this ratio constitutes a good approximation of small businesses' access to bank credit and apply it to study a sample of English small businesses.

The first model examines the relationship between bank debt and corporate characteristics of small businesses in the ICT industry. The independent variables for this first model are total assets (TA), profitability (PR), sales growth (GR), tangibility of assets (TA), earnings volatility (VO) and investment opportunities (IO).

These variables are, for each small business $i$, year $t$, defined as follows:

- $\quad T A=\operatorname{Ln}$ (total assets);

- $\quad \mathrm{PR}=\mathrm{ROA}$ (return on assets), net income divided by total assets;

- $\quad \mathrm{GR}=$ sales growth;

- $\quad \mathrm{TA}=$ tangible assets divided by total assets;

- $\quad \mathrm{VO}=$ Net profit variation factor;

- $\quad \mathrm{IO}=$ Tobin's Q ratio.

- $\quad \sum_{\mathrm{k}=2004}^{2006} \alpha_{\mathrm{K}}$ Year $\mathrm{K}=$ dichotomous variables for years 2004 to 2006;

- $\quad$ eit $=$ residuals.

The second model involves the same independent variables seen above with the addition of dichotomous variables for small business in the 'service' (SI) or 'production' (PI) industries as well as the interaction factors between these two dichotomous variables and the bank debt studied determinants.

The additional variables for the second model are, for each small business i, year $t$, defined as follows:

- $\quad \mathrm{SI}=1$ if the small business is part of the ICT service industry, 0 otherwise;

- $\quad \mathrm{PI}=1$ if the small business is part of the ICT production industry, 0 otherwise;

- The other variables are the interaction factors between the various studied determinants and the two dichotomous variables: SI and PI;

Note that the second model provides a deeper analysis. It attempts to examine the possible differences in the ICT industry between the two major service and production segments. These two segments may present risk levels evaluated differently by banking firms. Indeed, the economic model for service segment small businesses, in comparison with the production segment, is probably based more on the existence of intangible assets and development of human capital. These elements induce greater risk-taking for banks particularly due to the uncertain 
return on investment. This attitude by banks with regards to service segment small businesses may be largely explained by the greater likelihood of bankruptcy. Since, as discussed above, the availability of debt seems to depend directly on risk. This notion of risk may therefore differently affect access to bank debt depending on whether the small business belongs to the service segment or production segment. Thus, it is appropriate to study the interactions between various determinants for bank debt and the SI and PI variables using the second model. These interactions may be interpreted as if a separate study had been performed for each of the two ICT industry activity segments.

\section{EMPIRIC RESULTS}

\section{Descriptive Statistics}

Table 1 below presents the descriptive statistics. The dependant variable is composed of bank debt. On average, for our small business sample, it is $5.1 \%$ of total assets. This average varies from $0.1 \%$ of total assets for the first quartile to $6.6 \%$ for the last quartile. These observed averages are lower than those in previous studies conducted on small business samples from all industries (Cassar and Holmes, 2003, Sogorb-Mira, 2005, etc.).

With regards to independent variables, we note that total assets are 9,368. Profitability measured by the ROA (return on assets) ratio reaches an average of $0.7 \%$ which means that earnings for ICT industry small business represents an average less than $1 \%$ of total assets. Sales growth reaches an average of $50.4 \%$. Nevertheless, this average is $-5.2 \%$ for the first quartile and $40.9 \%$ for the third. Average tangibility equals $42 \%$ meaning that total assets for our small business sample is almost half composed of non-current assets. Earnings volatility is on the order of 63\%. Lastly, investment opportunities are 6.038. Among all these determinants retained for the purposes of this study, the investment opportunities variable demonstrates the highest 'variability' since its standard deviation is the highest.

Table I: Descriptive Statistics

\begin{tabular}{lcccccc}
\hline & Mean & Median & St. Dev. & \multicolumn{3}{c}{ Quartiles } \\
\cline { 5 - 6 } & & & & $\mathbf{2 5}$ & $\mathbf{5 0}$ & $\mathbf{7 5}$ \\
\hline BD & 0.051 & 0.093 & 0.001 & 0.013 & 0.066 & 0.050 \\
TA & 9,368 & 9,367 & 1,404 & 8,421 & 9,367 & 10,302 \\
PR & 0,007 & 0,020 & 0,167 & $-0,042$ & 0,020 & 0,078 \\
GR & 0,504 & 0,126 & 2,363 & $-0,052$ & 0,126 & 0,409 \\
AT & 0,420 & 0,384 & 0,242 & 0,214 & 0,384 & 0,608 \\
VO & 0,630 & $-0,278$ & 22,853 & $-1,032$ & $-0,278$ & 0,800 \\
IO & 6,038 & 1,194 & 43,997 & 0,479 & 1,194 & 3,285 \\
\hline
\end{tabular}

[See above for variable definitions]

Table 2 presents the Pearson correlation matrix between the independent variables. This table allows us to examine the possible degree of collinearity between various explicative variables. As expected, it shows certain statistically significant correlations. As an example, total accounting assets is positively correlated to tangibility at the $1 \%$ level. Also, total assets is negatively related to investment opportunities at the $1 \%$ level, demonstrating that companies whose total assets are large are those that have the least significant investment opportunities since we may consider that these firms have achieved their maturity phase. On the whole, and despite certain statistically significant correlations between explicative variables, the coefficients do not seem to be high enough (less than the 0.5 level determined by Grace and Hoh, 2005) to cause multi-collinearity issues. In comparison, the correlation levels obtained are comparable to those of Sogorb-Mira (2005) and Cassar and Holmes (2003). 
Table II: Pearson Correlation Matrix

\begin{tabular}{|c|c|c|c|c|c|c|}
\hline & TA & PR & GR & AT & VO & IO \\
\hline \multirow[t]{2}{*}{ TA } & 1 & $-0,128$ & $-0,058$ & 0,456 & 0,033 & $-0,284$ \\
\hline & & $(0,003)$ & $(0,184)$ & $(0,000)$ & $(0,454)$ & $(0,000)$ \\
\hline \multirow[t]{2}{*}{ PR } & & 1 & 0,044 & $-0,219$ & $-0,065$ & 0,010 \\
\hline & & & $(0,315)$ & $(0,000)$ & $(0,137)$ & $(0,819)$ \\
\hline \multirow[t]{2}{*}{$\mathrm{CR}$} & & & 1 & $-0,071$ & 0,068 & 0,015 \\
\hline & & & & $(0,106)$ & $(0,120)$ & $(0,731)$ \\
\hline \multirow[t]{2}{*}{ AT } & & & & 1 & 0,031 & $-0,117$ \\
\hline & & & & & $(0,483)$ & $(0,007)$ \\
\hline \multirow[t]{2}{*}{ VO } & & & & & 1 & 0,005 \\
\hline & & & & & & $(0,903)$ \\
\hline IO & & & & & & 1 \\
\hline
\end{tabular}

[See above for variable definitions]

\section{Multivariate Analysis}

Table 3 presents the empirical results from the first proposed multiple regression model. Note that only the profitability (PR) and size (TA) variables have statistically significant coefficients at the $1 \%$ level. Consequently, there are no statistically significant relationships at the $10 \%$ level between total assets (AT), sales growth (GR), volatility (VO), investment opportunities (IO) and the banking debt ratio (BD). These results may seem astonishing, at least with regards to the absence of a relationship between the level of bank debt and the firm's size (AT). In principle, a higher value for the firm measured by its total assets may provide potential creditors an interesting reimbursement guarantee with respect to an asset-based approach to solvability. This counter-intuitive result is nevertheless coherent with that found by Kremp and Stöss (2001) for a sample of French small businesses.

Consistent with the arguments of the pecking order theory, the firm's profitability is negatively related to bank financing. On the whole, these results are reported by most previous studies (Chittenden et al., 1996; Jordan et al., 1998; Michaelas et al., 1999). They confirm that managers of highly profitable companies prefer internal resources to external financing. Therefore, managers of ICT industry small business seem to favor financing sources that do not reduce their level of ownership and control.

Asset tangibility also affects access to bank debt for ICT industry small business. Indeed, tangibility is negatively and significantly correlated to the bank debt variable at the $1 \%$ level. The negative correlation between tangibility and bank debt contradicts the predications of the static trade-off theory. This unexpected result seems to highlight the difficulties encountered by ICT industry small businesses to finance their tangible asset elements using bank credit whereas the same asset elements provide physical guarantees for creditors. Applying this reasoning using information asymmetry in the bank financing domain is based on the fact that lenders have difficulty assessing borrowers' projects and monitoring their behavior. Borrowers have a much finer degree of information than lenders with regards to project viability, actual risks, and expected profitability. To reduce this information asymmetry, the credit institution may be tempted to implement monitoring mechanism whose effect will be to significantly increase management costs (collecting detailed information, financial analysis, periodic monitoring, etc.). A natural reaction may be to be more selective with regards to risks, which reduces the agency costs and the pricing level. This effect is probably more significant for ICT industry small businesses that for major firms for which the cost of collecting information is relatively less significant. Indeed the characteristics of ICT industry small businesses (immaterial assets, high R\&D presence, etc.) imply a greater probability of defaulting on repayment. The most risky projects are excluded from bank financing.

Table III: Results of the First Regression Model

\begin{tabular}{ccccccc}
\hline Intercept & TA & PR & GR & AT & VO & IO \\
\hline 0,105 & 0,033 & $-0,336$ & $-0,023$ & $-0,186$ & $-0,001$ & $-0,041$ \\
{$[3,324]$} & {$[0,654]$} & {$[-7,925]$} & {$[-0,557]$} & {$[-3,990]$} & {$[-0,024]$} & {$[-0,896]$} \\
$(0,001)$ & $(0,513)$ & $(0,000)$ & $(0,577)$ & $(0,000)$ & $(0,981)$ & $(0,371)$ \\
\hline Adj. $\mathbf{R}^{2}=11,3 \% / \mathrm{F} .=12,135 /$ P. $<1 \%$ & & & &
\end{tabular}

Note: Table 3 presents correlation coefficients, $[t]$ statistics and (P.) values

[See above for variable definitions] 
Table 4 presents the empirical results of the second considered model in this study. It highlights the relationship between the capital structure and bank debt ratio determinants based on whether the small business is part of the production or service segment. We have identified negative relationships between bank debt and the profitability and asset tangibility variables for both segments. Nevertheless, the sign is more significant for service segment. This means that the greater the profitability the less small business finance their growth using bank debt. This result is coherent with the arguments of the pecking order theory. Managers prefer to self-finance a large portion of their more risky investments, i.e. those that offer the highest profitability. Another explanation may be found in the banker/small business manager relationship. Banks refuse to grant credit to finance risky projects. So managers must cope with a moral hazard. They are obligated to find other sources of internal financing.

Production segment small businesses are the only ones that show a positive and significant relationship at the $10 \%$ level between their size and bank debt. This result corroborates certain previous empirical studies (Kashyap et al., 1996; Atanasova and Wilson 2004; and Bougheas et al., 2006). Nevertheless, our study's originality is in regards to service segment small businesses. Indeed, the size variable does not affect the level of bank debt for small businesses in this segment. Yet, asset size (TA) is a significant determinant conditioning access to bank credit. The size variable behaves as an approximation of the physical guarantees available (tangible fixed assets) for creditors. The explanation of this phenomenon may be found in bankers' perception with regards to the project's risk. They will be more inclined to finance tangible asset renewal or growth projects than projects aimed at establishing R\&D processes or purchasing a patent. So, the size criterion acts positively on bank debt if and only if the firm's total assets contain a majority of tangible assets. This is why the size variable is not significant for service segment ICT small businesses. More generally, this distinction between service and industrial small businesses seems pertinent in analyzing access to bank credit in so far as the former seem to be more rationed that the latter. The Basle Committee, guarantor of international prudential standards, seems to have taken this phenomenon into consideration in deploying a credit risk analysis adapted to various small business industries. This development currently underway in the Basle II regulations should theoretically incite banks to more finely apprehend the level of risk for investment projects and better adapt pricing. Indeed, regulatory capital will develop more strongly with the credit risk than under the former Basle I system. The results that we have highlighted demonstrate that this change in bank behavior with regards to ICT industry small businesses is not yet visible during our study period.

Table IV: Results of the Second Regression Model

\begin{tabular}{|c|c|c|c|c|c|c|c|c|}
\hline & Intercept & FA & TA & PR & GR & AT & VO & IO \\
\hline Group 1: & & & 0,631 & $-0,171$ & $-0,039$ & $-0,143$ & 0,060 & $-0,038$ \\
\hline \multirow[t]{3}{*}{ SI } & & & {$[1,604]$} & {$[-3,592]$} & {$[-0,866]$} & {$[-1,786]$} & {$[1,385]$} & {$[-0,751]$} \\
\hline & & & $(0,100)$ & $(0,000)$ & $(0,387)$ & $(0,075)$ & $(0,167)$ & $(0,453)$ \\
\hline & $\begin{array}{c}0,088 \\
{[2,631]} \\
(0,009)\end{array}$ & $\begin{array}{c}0,670 \\
{[1,606]} \\
(0,100)\end{array}$ & & & & & & \\
\hline Group 2: & & & 0,025 & $-0,303$ & $-0,009$ & $-0,215$ & $-0,037$ & $-0,027$ \\
\hline PI & & & {$[0,165]$} & {$[-7,051]$} & {$[-0,218]$} & {$[-3,610]$} & {$[-0,871]$} & {$[-0,587]$} \\
\hline & & & $(0,869)$ & $(0,000)$ & $(0,828)$ & $(0,000)$ & $(0,384)$ & $(0,558)$ \\
\hline
\end{tabular}

Note: Table 4 presents correlation coefficients, $[t]$ statistics and (P.) values

[See above for variable definitions]

\section{CONCLUSION}

Small business financing is of capital importance for the French economy, since small businesses, more than major groups, are vectors for innovation and employment. Their growth and durability depend, in part, on the way they obtain financing for their growth. The presence of intangible assets in ICT industry small businesses' balance sheets, particularly those in the service industry, requires banking firms to be prudent. On the basis of this remark, this article studied ICT industry small businesses' access to bank credit. This work was based on the pecking order and static-trade off theories. The empirical analysis involved a sample of 539 firm-years examined for a 4 year period from 2003 to 2006. This sample was divided into two groups: the first group included ICT industry small businesses belonging to the 'service' industry and the second those belonging to the 'production' industry. 
Several interesting results must be put into perspective. We obtained a negative relationship between profitability and bank debt, whether the firm belonged to the industrial or service segment, which is coherent with the predictions of the pecking order theory. ICT industry small business managers finance their investment primarily through internal resources. We also obtained a negative relationship between asset tangibility and the bank debt ratio. This unexpected result seems to raise the issue of credit rationing. This latter point seems more significant for 'service' segment small businesses. This contribution to the analysis of bank credit access for a sample of French ICT industry small businesses may provide some enlightenment and be of interest to all actors involved in small business financing such as researchers, finance professionals, banks, and governmental authorities.

\section{AUTHOR INFORMATION}

Dr. Ramzi Benkraiem is a Professor of Financial Accounting at IESEG School of Management and a researcher at the LEM center (CNRS, UMR 8179). His main research interests are firm financing policy and capital structure with a special focus on SMEs. He published several papers in both French and international peer reviewed journals. E-mail: r.benkraiem@ieseg.fr. Corresponding author.

Dr. Anthony Miloudi is a Professor of Finance at La Rochelle Business School, and a researcher at the CRIEF center - University of Poitiers. His current research interests concern corporate finance of small businesses. He published numerous papers in peer reviewed journals. E-mail: miloudia@esc-larochelle.fr

\section{REFERENCES}

1. Andrade, G. et Kaplan, S. (1998) 'How costly if financial (not economic) distress? Evidence from highly leveraged transactions that became distressed', Journal of Finance, Vol. 53, No. 5, pp. 1443-1494.

2. Atanasova, C.V et Wilson, N., (2004), 'Disequilibrium in the U.K. Corporate Loan Market', Journal of Banking and Finance, Vol. 28, pp. 595-614.

3. Aubier, M. et Cherbonnier, F. (2007) [in French], 'Firm access to bank credit', available at: http://www.cedef.minefi.gouv.fr/directions_services/dgtpe/TRESOR ECO/francais/pdf/2007-003-07.pdf

4. Blose, L.E. et Shieh, J.C.P. (1997) ‘Tobin’s Q ratio and Market Reaction to Capital Investment Announcements', The Financial Review, Vol. 32, No. 3, pp. 449-476.

5. Bougheas, S., Mizen, P et Yalcin, Y. (2006), 'Access to External Finance: Theory and Evidence on the Impact of Monetary Policy and Firm-Specific Characteristics', Journal of Banking and Finance, Vol. 30, pp. 199-227.

6. Cassar, G. et Holmes, S. (2003) 'Capital structure and financing of SMEs: Australian evidence', Accounting and Finance, Vol. 43, No. 2, pp. 123-147.

7. Chittenden, F., Hall, H. et Hutchinson, P. (1996) 'Small firm growth, access to capital markets and financial structure: Review of issues and empirical investigation', Small Business Economics, Vol. 8, No. 1, pp. 59-67.

8. DeAngelo, A. et Masulis, R. (1980) 'Optimal capital structure under corporate and personal taxation', Journal of Financial Economics, Vol. 8, No. 1, pp. 3-29.

9. Drobetz, W. et Fix, R. (2005) 'What are the Determinants of the Capital Structure? Evidence from Switzerland', Swiss Journal of Economics and Statistics, Vol. 141, No. 1, pp.71-113.

10. Gugler, K., Mueller, D.C. et Yurtoglu, B.B. (2004), 'Marginal Q, Tobin's Q, Cash Flow, and Investment', Southern Economic Journal, Vol. 70, No. 3, pp. 512-513.

11. Grace C.H. et Koh P.S., (2005), 'Does the presence of institutional investors influence accruals management? Evidence from Australia', Corporate Governance, Vol. 13, No. 6, pp. 809-823.

12. Jensen, M. et Meckling, W. (1976), 'Theory of the Firm: Managerial Behavior, Agency Costs and Ownership Structure', Journal of Financial Economics, Vol. 3, No. 4, pp. 305-360.

13. Jordan, J., Lowe, J, et Taylor, P. (1998) 'Strategy and Financial Policy in UK Small Firms', Journal of Business Finance and Accounting, Vol. 25, No. 1/2, pp.1-27.

14. Kashyap, A.K., Stein, J.C et Wilcox, D.W, (1996), 'Monetary Policy and Credit Conditions: Evidence from the Composition of External Finance: Reply', American Economic Review, Vol 86, pp. 310-314.

15. Kremp, E et Stöss, E., (2001) [in French], 'Debt structure of firms in France and Germany', Economie et Statistiques, No. 341/342, pp. 153-171. 
16. Lang, L.H.P. et Litzenberger, R.H. (1989) 'Dividend Announcements: Cash Flow Signaling versus Free Cash Flow Hypothesis?', Journal of Financial Economics, Vol. 24, No. 1, pp. 181-191.

17. Michaelas, N., Chittenden, F. et Poutziouris, P. (1999), 'Financial policy and capital structure choice in U.K. SMEs: Empirical evidence from company panel data', Small Business Economics, Vol. 12, No. 2, pp. 113-130.

18. Myers, S.C. (1984), 'The Capital Structure Puzzle', Journal of Finance, Vol. 39, No. 3, pp. 575-592.

19. Myers, S.C et Majluf, N.S. (1984), 'Corporate Financing and Investment Decisions When Firms Have Information that Investors Do Not Have', Journal of Financial Economics, Vol. 13, No. 2, pp. 187-221.

20. Oliner, S. et Rudebush, G., (1996), 'Monetary Policy and Credit Constraints: Evidence from the Composition of External Finance: Comment', American Economic Review, Vol 86, pp. 300-309.

21. Sogorb-Mira, F. (2005), 'How SME Uniqueness Affects Capital Structure', Small Business Economics, Vol. 25, No. 5, pp. 447-457.

22. Stiglitz, J et Weiss, A. (1981), 'Credit Rationing with Imperfect Information', American Economic Review, Vol 71, pp. 393-410.

23. Ziane, Y., (2004) [in French], 'Debt structure of French SMEs', Revue Internationale PME, vol. 17, ${ }^{\circ} 1$. 


\section{NOTES}

